\title{
1,25-Dihydroxyvitamin D Increases Calmodulin Binding to Specific Proteins in the Chick Duodenal Brush Border Membrane
}

\author{
Daniel D. Bikle and Scott Munson
}

Department of Medicine, Veterans Administration Medical Center, San Francisco, California 94121;

and University of California at San Francisco, California 94121

\begin{abstract}
In previous studies we demonstrated that the biologically active vitamin D metabolite 1,25-dihydroxyvitamin $D\left[1,25(\mathrm{OH})_{2} \mathrm{D}\right]$ increased the calmodulin (CaM) content of chick duodenal brush border membranes (BBM) without increasing the total cellular CaM content. Therefore, we evaluated the binding of CaM to discrete proteins in the BBM and determined whether $1,25(\mathrm{OH})_{2} \mathrm{D}$ could influence such binding. We observed one major and several minor CaM-binding bands on autoradiograms of sodium dodecyl sulfate polyacrylamide gels incubated with [ ${ }^{125}$ I]CaM. The major band had a molecular weight of 102,000105,000 . It bound CaM even in the presence of EGTA, but not in the presence of trifluoperazine or excess nonradioactive CaM. The administration of $1,25(\mathrm{OH})_{2} \mathrm{D}$ increased the apparent binding of CaM to this protein as assessed by densitometry of the autoradiogram. This increase in CaM binding coincided with the increased ability of the same BBM vesicles to accumulate calcium. Cycloheximide in doses that markedly reduced the incorporation of $\left[{ }^{35} \mathrm{~S}\right]$ methionine into BBM proteins did not reduce the ability of 1,25-dihydroxyvitamin $D_{3}$ to stimulate either calcium uptake by the BBM vesicles or CaM binding to the 102,000-105,000-mol-wt protein. These results suggest that $1,25(\mathrm{OH})_{2} \mathrm{D}$ administration increases the $\mathrm{CaM}$ content of duodenal BBM by increasing the ability of a 102,000-105,000-molwt protein to bind CaM. This mechanism may underlie the ability of $1,25(\mathrm{OH})_{2} \mathrm{D}$ to stimulate calcium movement across the intestinal BBM.
\end{abstract}

\section{Introduction}

Transcellular calcium transport across the intestine occurs in at least three steps (1-4): $(a)$ entry of calcium across the brush border membrane (BBM) ${ }^{1}$ down a steep electrochemical gradient into the cytoplasm; $(b)$ movement through the cytoplasm, probably within subcellular organelles; and $(c)$ removal across the basolateral membrane against a steep electrochemical gradient. Cellular fractionation techniques have made it possible to study each of these steps separately. From a number of studies it ap-

Address reprint requests to Dr. Daniel D. Bikle, VA Medical Center (111N), 4150 Clement Street, San Francisco, CA 94121. 1985

Received for publication 9 May 1985 and in revised form 15 July

1. Abbreviations used in this paper: $\mathrm{BBM}$, brush border membrane; BBMV, brush border membrane vesicles; CaM, calmodulin; $1,25(\mathrm{OH})_{2} \mathrm{D}$, 1,25-dihydroxyvitamin $\mathrm{D} ; 1,25(\mathrm{OH})_{2} \mathrm{D}_{3}$, 1,25-dihydroxyvitamin $\mathrm{D}_{3}$; SDS-PAGE, sodium dodecyl sulfate polyacrylamide gel electrophoresis; TFP, trifluoperazine.

The Journal of Clinical Investigation, Inc.

Volume 76, December 1985, 2312-2316 pears likely that the principal hormonal regulator of intestinal calcium transport, 1,25-dihydroxyvitamin $\mathrm{D}\left[1,25(\mathrm{OH})_{2} \mathrm{D}\right]$, affects calcium transport at each step, but by different mechanisms (5-9).

Calcium accumulation by purified brush border membrane vesicles (BBMV) is the best-studied in vitro model used to evaluate the first step in intestinal calcium transport, namely, entry of calcium from the lumen into the cell. This process does not require ATP. Administration of $1,25(\mathrm{OH})_{2} \mathrm{D}$ in vivo to vitamin D-deficient chicks results in an enhanced ability of the subsequently isolated BBMV to accumulate calcium $(5,10,11)$. Hypotheses explaining this effect include the synthesis of new proteins such as IMcal (12) or the vitamin D-dependent calciumbinding protein (13), and changes in the lipid composition of the $\operatorname{BBM}(14,15)$.

Our previous studies with cycloheximide $(7,9,16)$ have indicated that new protein synthesis is not required for $1,25(\mathrm{OH})_{2} \mathrm{D}$ to stimulate calcium entry into the cell across the BBM. Similarly, our studies with fluorescence depolarization (17) have shown that gross changes in membrane fluidity (via changes in lipid composition) are not required for $1,25(\mathrm{OH})_{2} \mathrm{D}$ to stimulate calcium entry into the cell across the BBM. Accordingly, we considered other possible mechanisms and found that $1,25(\mathrm{OH})_{2} \mathrm{D}$ administration to vitamin D-deficient chicks led to an increase in calmodulin ( $\mathrm{CaM})$ content in the BBM without a comparable increase in total cellular CaM levels (18). Since the BBM were prepared in buffers containing EGTA, the CaM binding to the BBM presumably occurred despite the near absence of calcium. The increase in $\mathrm{CaM}$ content coincided with the increase in calcium-accumulating ability; $\mathrm{CaM}$ antagonists blocked the increased calcium-accumulating ability. By inference, CaM mediated the effect of $1,25(\mathrm{OH})_{2} \mathrm{D}$ on calcium accumulation by the BBMV.

This report considers how $1,25(\mathrm{OH})_{2} \mathrm{D}$ effects an increase in $\mathrm{CaM}$ content in the BBM in the absence of calcium without stimulating $\mathrm{CaM}$ production. We approached the question by analyzing the calcium-binding proteins in the BBM by the CaM gel overlay procedure of Glenney and Weber (19). Our results indicate that a protein with a molecular weight of $\sim 102,000$ 105,000 binds $\mathrm{CaM}$ in the virtual absence of calcium $(1 \mathrm{mM}$ EGTA). This binding is increased by $1,25(\mathrm{OH})_{2} \mathrm{D}$ even under circumstances (cycloheximide) in which protein synthesis is inhibited.

\section{Methods}

Animals. White Leghorn cockerels were raised from hatching for $6 \mathrm{wk}$ on a vitamin D-deficient diet containing $1 \%$ calcium and $0.65 \%$ phosphorus. The $1,25(\mathrm{OH})_{2} \mathrm{D}$, obtained as a gift from M. R. Uskokovic, Hoffmann-LaRoche Inc. (Nutley, NJ), was administered in 625-pmol doses in $100 \mu$ l propylene glycol to some of the animals via gastric tube. Cycloheximide was administered intraperitoneally, $20 \mu \mathrm{g} / 100 \mu \mathrm{l}$ propylene glycol, every $4 \mathrm{~h}$ to some of the animals, beginning $1 \mathrm{~h}$ before 
the administration of $1,25(\mathrm{OH})_{2} \mathrm{D}$. Control animals received vehicle (orally and/or intraperitoneally) as appropriate. At different times after the administration of 1,25-dihydroxyvitamin $\mathrm{D}_{3}\left[1,25(\mathrm{OH})_{2} \mathrm{D}_{3}\right]$, groups of five or six chicks were anesthetized with pentobarbital, the duodena removed, and BBMV were prepared from the duodena of these animals by the method of Max et al. (20), except that $0.1 \mathrm{mM}$ phenylmethylsulfonylfluoride was included in all buffers to reduce the possibility of proteolysis during the preparation.

Calcium transport in BBMV. Calcium uptake was measured as previously described (11) by incubating $0.5 \mathrm{mg} \mathrm{BBMV}$ protein in $1 \mathrm{ml} 75$ $\mathrm{mM}$ Tris-Cl, $75 \mathrm{mM}$ 2[ $N$-morpholino]ethane sulfonic acid, $75 \mathrm{mM}$ choline $\mathrm{Cl}, 0.5 \mathrm{mM} \mathrm{MgCl} 2$ at $\mathrm{pH} 7.0$ (buffer A). After $15 \mathrm{~min}, 25 \mu \mathrm{ll} 100$ $\mathrm{mM} \mathrm{CaCl} 2$ containing $10 \mu \mathrm{Ci}^{45} \mathrm{Ca}$ (Amersham Corp., Arlington Heights, IL) were added. After $30 \mathrm{~min}, 100-\mu \mathrm{l}$ aliquots were removed and washed through 7.5-cm columns of AG-50W-X8 50-100-mesh cation exchange resin in Tris form (Bio-Rad Laboratories, Richmond, CA) into scintillation vials with $2 \mathrm{ml} 0.25 \mathrm{M}$ sucrose (no buffer). The ${ }^{45} \mathrm{Ca}$ radioactivity in the eluate was determined by liquid scintillation spectroscopy. The columns were prepared in disposable Pasteur pipettes plugged with glass wool and washed with $5 \mathrm{ml} 0.25 \mathrm{M}$ sucrose in $10 \mathrm{mM}$ Tris-Cl, pH 8.0. Before use, $100 \mu \mathrm{l} 10 \mathrm{~g}$ bovine serum albumin/100 ml were washed through the column with $5 \mathrm{ml} 0.25 \mathrm{M}$ sucrose in $10 \mathrm{mM}$ Tris-Cl, pH 8.0.

CaM-binding proteins. CaM-binding proteins in the BBM were detected using the $\left.{ }^{125} \mathrm{I}\right] \mathrm{CaM}$ gel overlay procedure of Glenney and Weber (19), as modified by Nelson et al. (21). Equal aliquots of BBMV proteins (e.g., $250 \mu \mathrm{g}$ ) from the preparations to be compared were subjected to sodium dodecyl sulfate polyacrylamide gel electrophoresis (SDS-PAGE) by the method of Laemmli (22) using $8 \%$ polyacrylamide gels. Subsequent to electrophoresis the gels were fixed in $40 \% \mathrm{MeOH} / 10 \%$ acetic acid, washed first in $10 \%$ ethanol, then in water, and incubated in 3-5 $\mu \mathrm{Ci}$ $\left[{ }^{125} \mathrm{I}\right] \mathrm{CaM} / \mathrm{gel}$. This incubation medium contained $1 \mathrm{mM} \mathrm{CaCl}, 1 \mathrm{mM}$ EGTA, $10^{-4} \mathrm{M}$ trifluoperazine (TFP), or $10 \mu \mathrm{g} / \mathrm{ml} \mathrm{CaM}$, depending on the experiment. $\left.{ }^{125} \mathrm{I}\right] \mathrm{CaM}$ and unlabeled $\mathrm{CaM}$ were gifts from Dr. James Chafouleas, Centre de Recherche Endocrinol Moleculaire, Centre Hôpitale de l'Université de Laval, Ste. Foy, Quebec, Canada. After the 18-h incubation, the gels were washed, stained with Coomassie Blue, photographed, dried, and exposed to X-Omat film (Eastman Kodak Co., Rochester, NY) for $7-21 \mathrm{~d}$ at $-80^{\circ} \mathrm{C}$. The autoradiograms were developed, then scanned by a densitometer (E-C Apparatus Corp., St. Petersburg, FL) using identical settings for all samples in each experiment. The densitometer tracings of each peak were quantitated by determining the area under the peak.

$\left[{ }^{35} S\right]$ Methionine incorporation. To label newly synthesized proteins in the BBM, the in situ duodenal loop preparation originally described by Coates and Holdsworth (23) and modified by Morrissey et al. (24) was used. $50 \mu \mathrm{Ci}\left[{ }^{35} \mathrm{~S}\right]$ methionine (specific activity, $1,435 \mathrm{Ci} / \mathrm{mmol}$, Amersham Corp.) in $300 \mu$ l buffer $(120 \mathrm{mM} \mathrm{NaCl}, 25 \mathrm{mM} \mathrm{4-(2-hy-}$ droxyethyl)-1-piperazineethanesulfonic acid, $6 \mathrm{mM} \mathrm{KCl,} 1 \mathrm{mM} \mathrm{MgSO}_{4}$, $20 \mathrm{mM}$ glucose) was injected into the lumen of a 5-cm loop of proximal duodenum under pentobarbital anesthesia; the loop with blood supply intact was placed back into the peritoneal cavity. After $15 \mathrm{~min}$ the animal was killed, the duodenal loop was removed and rinsed free of luminal contents, and BBMV were prepared as described above. Six animals were used for each BBMV preparation. Samples containing $300 \mu \mathrm{g}$ BBMV were analyzed by SDS-PAGE and autoradiography ( 1 mo exposure to $\mathrm{X}$-Omat film) as described above.

Other assays. Protein concentrations were performed by the method of Lowry et al. (25). Alkaline phosphatase determinations were performed by the method of Hausamen et al. (26).

\section{Results}

The principal CaM-binding protein in duodenal BBMV has an apparent molecular weight of 102,000-105,000 (Fig. 1). More apparent in Fig. 3 than in Fig. 1 is the presence of other CaMbinding proteins, including those with molecular weights of $\sim 88,000,78,000$, and 52,000 . The binding of $\mathrm{CaM}$ to the

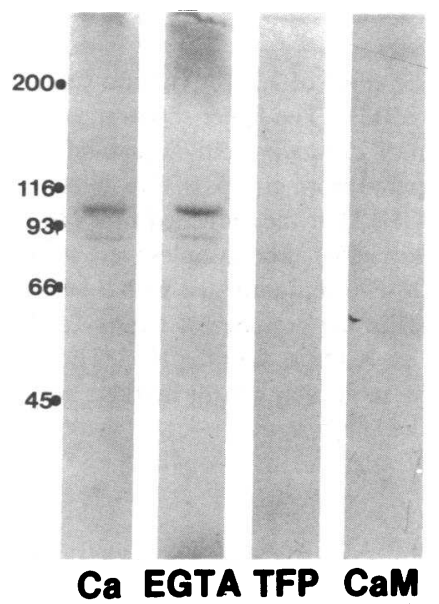

Figure 1. The effects of calcium, trifluoperazine, and excess $\mathrm{CaM}$ on $\left.{ }^{125} \mathrm{I}\right] \mathrm{CaM}$-binding to BBM protein. Aliquots of the same BBMV preparation (150 $\mu \mathrm{g}$ protein/aliquot) were applied to four gels, and the proteins were separated by SDS-PAGE. $3 \mu \mathrm{Ci}\left[^{125} \mathrm{I}\right] \mathrm{CaM}$ was incubated with each gel in the presence of $1 \mathrm{mM} \mathrm{CaCl}_{2}$ (Ca), 1 mM EGTA (EGTA), 1 $\mathrm{mM} \mathrm{CaCl} 2$ plus $10^{-4} \mathrm{M}$ TFP (TFP), or $1 \mathrm{mM} \mathrm{CaCl}{ }_{2}$ plus 10 $\mu \mathrm{g} / \mathrm{ml} \mathrm{CaM} \mathrm{(CaM).} \mathrm{Subsequent}$ to this incubation, the gels were placed on X-Omat film for 1 wk. The autoradiograms are shown with the positions of the molecular weight markers on the left margin. The 102,000-105,000-mol-wt CaM-binding protein binds $\left.{ }^{[25} \mathrm{I}\right] \mathrm{CaM}$ in the presence of EGTA, but not in the presence of TFP or excess CaM.

$102,000-105,000-, 88,000-$, and $78,000-\mathrm{mol}$ wt proteins is not eliminated by incubating the gel with $\left[{ }^{125} \mathrm{I}\right] \mathrm{CaM}$ in the presence of $1 \mathrm{mM}$ EGTA (see Fig. 1). However, $10^{-4}$ TFP and excess nonradioactive $\mathrm{CaM}$ eliminated all detectable $\mathrm{CaM}$ binding to these bands (Fig. 1).

When $1,25(\mathrm{OH})_{2} \mathrm{D}$ was administered to vitamin D-deficient chicks at $0,4,9,12,18$, or $24 \mathrm{~h}$ before removing the duodena and preparing the BBMV, calcium accumulation by the BBMV from chicks receiving $1,25(\mathrm{OH})_{2} \mathrm{D}$ was greater than that from chicks receiving only vehicle (the zero hour group) (Fig. 2). This effect was observed by $4 \mathrm{~h}$ and was maximal by $8-12 \mathrm{~h}$ after $1,25(\mathrm{OH})_{2} \mathrm{D}$ administration. The autoradiogram of these six preparations of BBMV analyzed for CaM-binding proteins is shown in Fig. 3. The most striking change is in the CaM binding of the 102,000-105,000-mol-wt protein. Quantitation of the density of the 102,000-105,000-, 88,000-, 78,000-, and 52,000mol-wt bands is shown in Fig. 4. The densitometric tracings indicate that $1,25(\mathrm{OH})_{2} \mathrm{D}$ increases $\mathrm{CaM}$ binding to the 102,000 105,000-mol-wt protein $\sim 10$-fold, with a threefold stimulation of CaM binding to the 88,000 -mol-wt protein. Most of the stimulation is seen within the first $12 \mathrm{~h}$ after $1,25(\mathrm{OH})_{2} \mathrm{D}$ administration. The effect of $1,25(\mathrm{OH})_{2} \mathrm{D}$ on the other CaM-binding proteins $(78,000-\mathrm{mol}-\mathrm{wt}$ and $52,000-\mathrm{mol}-\mathrm{wt})$ is less apparent. The increase in CaM binding to the 102,000 -mol-wt protein is accompanied by a subtle but evident increase in protein content of the 102,000-mol-wt band as assessed by Coomassie Blue staining of the gel (data not shown).

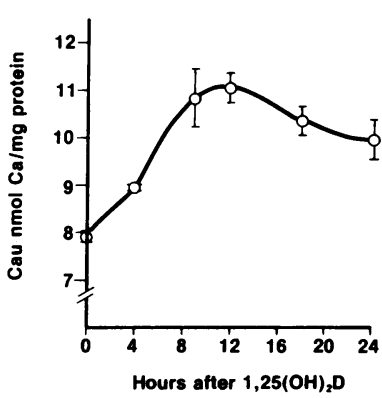

Figure 2. The effects of $1,25(\mathrm{OH})_{2} \mathrm{D}$ on calcium accumulation by BBMV. Measurement was taken of calcium accumulation (CaU) by BBMV, prepared from groups of five chicks given $1,25(\mathrm{OH})_{2} \mathrm{D}$ at the indicated times before they were killed. Maximal calcium accumulation is seen by 8-12 h. The error bars enclose mean \pm range of duplicate determinations. 


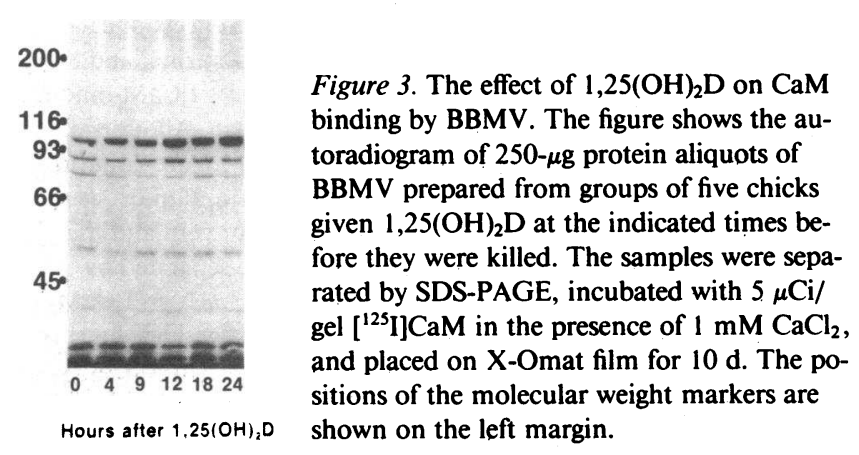

To determine whether the increased $\mathrm{CaM}$ binding to the $102,000-105,000$-mol-wt protein after $1,25(\mathrm{OH})_{2} \mathrm{D}$ administration required new protein synthesis, we administered a protein synthesis inhibitor, cycloheximide, to some of the animals using a protocol (16) that prevented the induction of the vitamin Ddependent calcium-binding protein by $1,25(\mathrm{OH})_{2} \mathrm{D}$. Four groups of 12 animals were studied: group A received only vehicle, group B received only $1,25(\mathrm{OH})_{2} \mathrm{D}$, group $\mathrm{C}$ received only cycloheximide, and group $\mathrm{D}$ received both cycloheximide and $1,25(\mathrm{OH})_{2} \mathrm{D}$. $12 \mathrm{~h}$ after receiving $1,25(\mathrm{OH})_{2} \mathrm{D}$ (or vehicle), six of the animals in each group were incubated with $\left[{ }^{35} \mathrm{~S}\right]$ methionine using in situ duodenal loops to assess synthesis of BBMV proteins. The remaining six animals were used to assess calciumaccumulation, alkaline phosphatase, and CaM-binding proteins in BBMV. As seen in Table $\mathrm{I}, 1,25(\mathrm{OH})_{2} \mathrm{D}$ administration resulted in nearly a threefold increase in alkaline phosphatase activity and a $43 \%$ increase in calcium-accumulating ability by the BBMV. Cycloheximide alone reduced alkaline phosphatase activity but not calcium-accumulating ability. Cycloheximide inhibited the ability of $1,25(\mathrm{OH})_{2} \mathrm{D}$ to stimulate alkaline phosphatase activity, but did not inhibit its ability to stimulate calcium accumulation.

The autoradiogram of $\left[{ }^{35} \mathrm{~S}\right]$ methionine-labeled BBM proteins from these four groups of animals is shown in Fig. $5.1,25(\mathrm{OH})_{2} \mathrm{D}$ appears to increase $\left[{ }^{35} S\right]$ methionine incorporation into several proteins including a $10 \%$ increase (by densitometry) into a band with a molecular weight of 102,000-105,000. However, the in vivo administration of cycloheximide nearly totally blocks

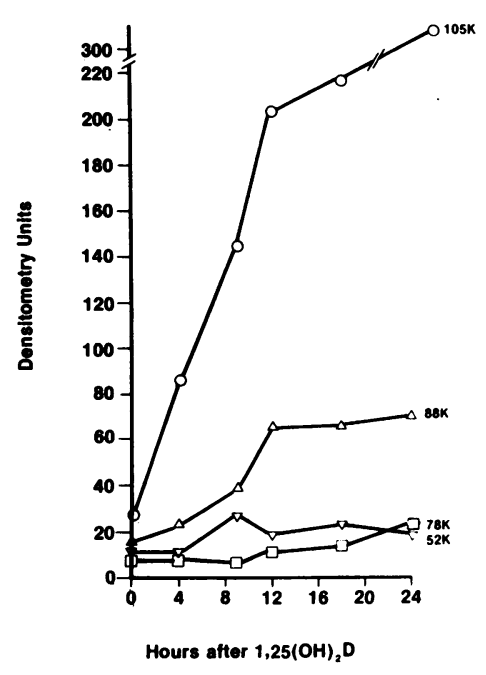

Figure 4. Quantitation of CaM binding by densitometry. The major peaks of the densitometric scans of the autoradiogram shown in Fig. 3 were quantitated in arbitrary densitometric units and plotted as a function of time after the administration of $1,25(\mathrm{OH})_{2} \mathrm{D}$. This plot indicates that $1,25(\mathrm{OH})_{2} \mathrm{D}$ increases $\mathrm{CaM}$ binding to the 102,000-105,000-mol-wt protein $\sim 10$-fold with lesser effects on the other CaM-binding proteins.
Table I. Effects of Cycloheximide on 1,25(OH $)_{2}$ D-stimulated Alkaline Phosphatase and Calcium Accumulation by BBMV

\begin{tabular}{llllc}
\hline & Control & $1,25(\mathrm{OH})_{2} \mathrm{D}$ & Cycloheximide & $\begin{array}{c}1,25(\mathrm{OH})_{2} \mathrm{D} \text { and } \\
\text { cycloheximide }\end{array}$ \\
\hline Alk pase & $9.6 \pm 0.3^{*}$ & $27.4 \pm 2.2$ & $4.0 \pm 0.3$ & $5.6 \pm 0.4$ \\
$\mathrm{CaU}$ & $7.1 \pm 0.4 \dagger$ & $10.1 \pm 0.6$ & $7.7 \pm 0.4$ & $10.2 \pm 0.2$ \\
\hline
\end{tabular}

* Nanomoles per minute per microgram protein \pm range of duplicate determinations.

$\dagger$ Nanomoles Ca per milligram protein \pm range of duplicate determinations. In this experiment, groups of six animals received cycloheximide (or vehicle) in $20 \mu \mathrm{g} / 1 \mathrm{GO} \mu \mathrm{l}$ doses i.p. every $4 \mathrm{~h}$, beginning $1 \mathrm{~h}$ before the oral administration of $625 \mathrm{pmol} 1,25(\mathrm{OH})_{2} \mathrm{D}$ (or vehicle). $12 \mathrm{~h}$ after receiving $1,25(\mathrm{OH})_{2} \mathrm{D}$ (or vehicle) the animals were killed and BBMV was prepared.

$\left.{ }^{[35} \mathrm{S}\right] \mathrm{methionine}$ labeling of these proteins and prevents the increase of such labeling by $1,25(\mathrm{OH})_{2} \mathrm{D}$. No labeling of the $102,000-105,000$-mol-wt protein was observed in the cycloheximide-treated chicks.

The autoradiogram following [ $\left.{ }^{125} \mathrm{I}\right] \mathrm{CaM}$-binding to BBM proteins from these four groups of animals is shown in Fig. 6. As expected, $1,25(\mathrm{OH})_{2} \mathrm{D}$ increased the $\mathrm{CaM}$ binding to the 102,000-105,000-mol-wt protein. Cycloheximide did not reduce $\mathrm{CaM}$ binding to this protein below that observed in the control animals, nor did it block the stimulation of $\mathrm{CaM}$ binding to this protein by $1,25(\mathrm{OH})_{2} \mathrm{D}$.

\section{Discussion}

The mechanism(s) by which $1,25(\mathrm{OH})_{2} \mathrm{D}$ stimulates intestinal calcium transport remains unclear, although support is growing for the concept that multiple mechanisms are involved (1-5). The stimulation of calcium flux across the BBM occurs fairly rapidly (within $2 \mathrm{~h}$ ), and does not appear to require new protein synthesis $(2,5,9,16,17,27)$. This stimulation correlates with selective fatty acid changes in the phosphatidylcholine component of the membrane (15), although the biological significance of these changes in lipid composition remains uncertain (17, 28). We (18) have been attracted to the possibility that $\mathrm{CaM}, \mathrm{a}$ calcium-binding protein whose total concentration in the intestinal epithelial cell is not altered by $1,25(\mathrm{OH})_{2} \mathrm{D}(18,29)$, might mediate $1,25(\mathrm{OH})_{2} \mathrm{D}$ action on calcium transport. In this proposed scheme, $1,25(\mathrm{OH})_{2} \mathrm{D}$ effects a redistribution of $\mathrm{CaM}$ within

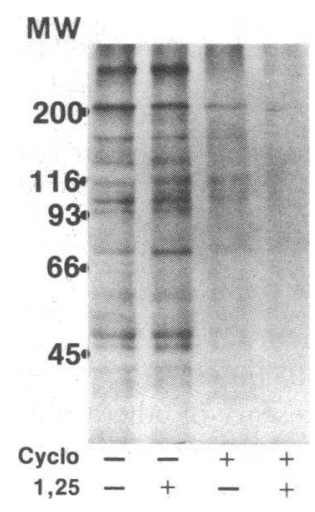

Figure 5. The effect of cycloheximide on BBMV protein synthesis. The autoradiogram of ${ }^{35}$ S $]$ methionine-labeled BBM proteins separated by SDS-PAGE is shown. Each lane contains $300-\mu$ g protein aliquots of BBMV from groups of six chicks treated with or without cycloheximide (cyclo) and with or without $1,25(\mathrm{OH})_{2} \mathrm{D}(1,25)$ as described in the legend to Table I. The positions of the molecular markers are shown on the left margin. 


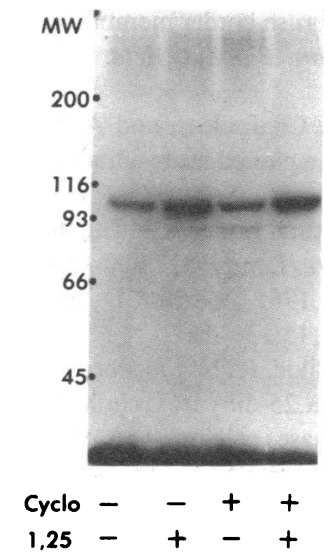

Figure 6. The effects of cycloheximide on $\mathrm{CaM}$ binding to BBMV proteins. The autoradiogram of $300-\mu \mathrm{g}$ protein aliquots of BBMV prepared from groups of six chicks treated with or without cycloheximide (cyclo) and with or without $1,25(\mathrm{OH})_{2} \mathrm{D}$ $(1,25)$ as described in the legend to Table I. The BBMV proteins were separated by SDS-PAGE, incubated in $4 \mu \mathrm{Ci} / \mathrm{gel}$ [25I]CaM in the presence of $1 \mathrm{mM}$ EGTA, then placed on X-Omat film for 3 wk. The positions of the molecular markers are shown on the left margin.

the cell rather than new protein (CaM) synthesis. In support of this model, we have observed an increase in the CaM content of the BBM following $1,25(\mathrm{OH})_{2} \mathrm{D}$ administration, which coincides with an increased capacity of the purified BBMV to accumulate calcium. CaM antagonists block the enhanced calciumaccumulating ability by BBMV from chicks receiving $1,25(\mathrm{OH})_{2} \mathrm{D}$.

Implicit in the above scheme is the requirement that $1,25(\mathrm{OH})_{2} \mathrm{D}$ increases the ability of the BBMV to bind CaM. Thus, we evaluated the effect of $1,25(\mathrm{OH})_{2} \mathrm{D}$ on CaM-binding proteins in the BBMV. We were particularly interested in finding a protein that did not require calcium to bind $\mathrm{CaM}$, because the first step in regulating calcium entry into the cell across the BBM should be independent of changes in intracellular calcium concentration. Otherwise, the process would more likely be secondary to the changes in calcium entry rather than mediating these changes. In addition, such a protein needed to be able to bind $\mathrm{CaM}$ and to increase this binding after $1,25(\mathrm{OH})_{2} \mathrm{D}$ administration by a cycloheximide-insensitive process in order to qualify as a possible mediator of the cycloheximide-insensitive $1,25(\mathrm{OH})_{2}$ D-stimulated calcium movement across the BBM. In this report we describe a 102,000-105,000-mol-wt CaM-binding protein that appears to meet these requirements. Its ability to bind $\mathrm{CaM}$ increases after $1,25(\mathrm{OH})_{2} \mathrm{D}$ administration coincident with the increased ability of the BBMV to accumulate calcium. This ability to bind CaM does not require calcium and is not inhibited by cycloheximide. Other calcium-independent CaMbinding proteins $(88,000 \mathrm{~mol} \mathrm{wt}$ and $78,000 \mathrm{~mol} \mathrm{wt})$ were observed, but their ability to bind $\mathrm{CaM}$ was variable and always less than the 102,000-105,000-mol-wt protein. These smaller CaM-binding proteins may be degradation products of the 102,000-105,000-mol-wt CaM-binding protein (30).

Other investigators have described a calcium-independent CaM-binding protein of similar or slightly larger size $(105,000$ 110,000-mol-wt) in chick intestinal BBM $(19,30,31)$. Localization studies have suggested that this protein forms a bridge between the plasma membrane and microfilament core of the microvilli $(32,33)$. A recent study observed that this protein had myosin-like ATPase activity (34), but its function in the microvillus is unclear. Glenney and Glenney (35) have proposed, on the basis of detergent solubilization, that this protein is an integral part of the membrane, where it could conceivably serve a function such as calcium transport. In this regard, they (36) have recently demonstrated a complex interaction between $\mathrm{pH}$, calcium, and $\mathrm{CaM}$ binding to this protein, which may facilitate

its role as a transporter of calcium across the membrane into the cytosol. On the other hand, Verner and Bretscher (30) have presented evidence that this protein is bound to the microvillus cytoskeleton, from which it can be dissociated with ATP, and is not an integral part of the membrane. The BBMV preparation that we have analyzed has been prepared in such a way as to remove the bulk of the microvillus cytoskeleton (20). As such we did not observe the TW-260/240 or 140,000-mol-wt CaMbinding proteins described by Glenney et al. (19) that are present in the microvillus cytoskeleton. In unpublished studies we have been unable to extract the 102,000-105,000-mol-wt protein from the BBMV with ATP, but have readily extracted it with a variety of detergents. Thus, our own studies support the concept that in the BBM preparation we have studied, the 102,000-105,000mol-wt protein is an integral part of the membrane. This does not exclude an additional localization of the 102,000-105,000 mol-wt (or 105,000-110,000 mol wt) protein in the microvillus cytoskeleton. We assume, but have no definite evidence, that the 102,000-105,000-mol-wt CaM-binding protein in the BBM is the same or is derived from the 105,000-110,000-mol-wt CaMbinding protein in the cytoskeleton.

In the current report, we have observed that $1,25(\mathrm{OH})_{2} \mathrm{D}_{3}$ increases the binding of CaM to the 102,000-105,000-mol-wt protein without stimulating new protein synthesis. In contrast, Howe et al. (37) reported a consistent decrease in CaM binding to a 105,000 -mol-wt protein in the microvillus cytoskeleton when rachitic chickens were given vitamin $\mathrm{D}$. Conceivably, $1,25(\mathrm{OH})_{2} \mathrm{D}_{3}$ administration results in a translocation of the $102,000-105,000$-mol-wt protein from the microvillus cytoskeleton to the membrane. Such a mechanism would reconcile the results obtained by Howe et al. with our own. The slightly smaller size that we observe (102,000-105,000 mol wt) for this CaM-binding protein in the BBM relative to that reported by others for the CaM-binding protein in the microvillus cytoskeleton (105,000-110,000 mol wt) suggests a structural alteration during the translocation, but such differences need to be confirmed.

In summary, we hypothesize that the 102,000-105,000-molwt CaM-binding protein plays an important role in regulating calcium movement across the BBM. In our model we postulate that $\mathrm{CaM}$ activates this protein. $1,25(\mathrm{OH})_{2} \mathrm{D}$ could increase the binding of $\mathrm{CaM}$ to this protein through several mechanisms, none of which requires new protein synthesis; examples of these are translocation from another cellular location such as the microvillus cytoskeleton, phosphorylation of the protein, cleavage of a precursor, and inhibition of its degradation. However, both the role (if any) of this protein in calcium transport and the mechanism by which $1,25(\mathrm{OH})_{2} \mathrm{D}$ increases its binding to $\mathrm{CaM}$ need to be established.

\section{Acknowledgments}

We thank J. G. Chafouleas for reagents and advice, Cheryl Holzaepfel for editorial assistance, and Irene Bertolucci for graphics assistance.

This work was supported by grants from the Veterans Administration and the National Institutes of Health (AM 28116).

\section{References}

1. Bikle, D. D., R. L. Morrissey, D. T. Zolock, and H. Rasmussen. 1981. The intestinal response to vitamin D. Rev. Physiol. Biochem. Pharmacol. 89:63-142. 
2. Wasserman, R. H., M. E. Brindak, S. A. Meyer, and C. S. Fullmer. 1982. Evidence for multiple effects of vitamin $D_{3}$ on calcium absorption: response of rachitic chicks, with or without partial vitamin $\mathrm{D}_{3}$ repletion, to 1,25-dihydroxyvitamin $\mathrm{D}_{3}$. Proc. Natl. Acad. Sci. USA. 79:7939-7943.

3. Tanaka, Y., H. F. DeLuca, J. Omdahl, and M. F. Holick. 1971. Mechanism of action of 1,25-dihydroxycholecalciferol in intestinal calcium transport. Proc. Natl. Acad. Sci. USA. 68:1286-1288.

4. Norman, A. W., J. A. Putkey, and I. Nemere. 1982. Intestinal calcium transport: pleiotropic effects mediated by vitamin D. Fed. Proc. 41:78-83.

5. Rasmussen, H., O. Fontaine, E. E. Max, and D. B. P. Goodman. 1979. The effect of $1 \alpha$-hydroxyvitamin $D_{3}$ administration on calcium transport in chick intestine brush border membrane vesicles. J. Biol. Chem. 254:2993-2999.

6. Bikle, D. D., E. W. Askew, D. T. Zolock, R. L. Morrissey, and R. H. Herman. 1980. Calcium accumulation by chick intestinal mitochondria: regulation by vitamin $D_{3}$ and 1,25-dihydroxyvitamin $D_{3}$. Biochim. Biophys. Acta. 598:561-574.

7. Morrissey, R. L., D. T. Zolock, P. W. Mellick, and D. D. Bikle. 1980. Influence of cycloheximide and 1,25-dihydroxyvitamin $D_{3}$ on mitochondrial and vesicle mineralization in the intestine. Cell Calcium. 1: 69-79.

8. Van Os, C. H., and W. E. J. M. Ghijsen. 1983. Mechanism of active calcium transport in basolateral plasma membranes of rat small intestinal epithelium. In Intestinal Transport. M. Gilles-Baillien and R. Gilles, editors. Springer-Verlag, Berlin. 172-183.

9. Bikle, D. D., R. L. Morrissey, and D. T. Zolock. 1979. The mechanism of action of vitamin D in the intestine. Am. J. Clin. Nutr. 32: 2322-2338.

10. Miller, A., III, and F. Bronner. 1981. Calcium uptake in isolated brush border vesicles from rat small intestine. Biochem. J. 196:391-401.

11. Bikle, D. D., S. J. Munson, and D. T. Zolock. 1983. Calcium flux across chick duodenal brush border membrane vesicles: regulation by 1,25-dihydroxyvitamin D. Endocrinology. 113:2072-2080.

12. Schachter, D., and S. Kowarski. 1982. Isolation of the protein IM Cal, a vitamin D-dependent membrane component of the intestinal transport mechanism for calcium. Fed. Proc. 41:84-87.

13. Feher, J. J., and R. H. Wasserman. 1979. Studies on the subcellular localization of the membrane-bound fraction of intestinal calcium-binding protein. Biochim. Biophys. Acta. 585:599-610.

14. O'Doherty, P. J. A. 1979. 1,25-dihydroxyvitamin $D_{3}$ increases the activity of the intestinal phosphatidylcholine deacylation-reacylation cycle. Lipids. 14:75-77.

15. Matsumoto, T., O. Fontaine, and H. Rasmussen. 1981. Effect of 1,25-dihydroxyvitamin $D_{3}$ on phospholipid metabolism in chick duodenal mucosal cell. J. Biol. Chem. 256:3354-3360.

16. Bikle, D. D., D. T. Zolock, R. L. Morrissey, and R. H. Herman. 1978. Independence of 1,25-dihydroxyvitamin $D_{3}$-mediated calcium transport from de novo RNA and protein synthesis. J. Biol. Chem. 253: 484-488.

17. Bikle, D. D., J. Whitney, and S. Munson. 1984. The relationship of membrane fluidity to calcium flux in chick intestinal brush border membranes. Endocrinology. 114:260-267.

18. Bikle, D. D., S. Munson, and J. G. Chafouleas. 1984. Calmodulin may mediate 1,25-dihydroxyvitamin D-stimulated intestinal calcium transport. FEBS (Fed. Eur. Biochem. Soc.) Lett. 174:30-33.

19. Glenney, J. R., Jr., and K. Weber. 1980. Calmodulin-binding proteins of the micro-filaments present in isolated brush borders and microvilli of intestinal epithelial cells. J. Biol. Chem. 255:10551-10554.

20. Max, E. E., D. B. P. Goodman, and H. Rasmussen. 1978. Pu- rification and characterization of chick intestine brush border membrane: effects of $1 \alpha \mathrm{OH}$ vitamin $\mathrm{D}_{3}$ treatment. Biochim. Biophys. Acta. 511: 224-239.

21. Nelson, T. Y., J. M. Overweller, J. G. Chafouleas, and A. E. Boyd III. 1983. Calmodulin-binding proteins in a cloned rat insulinoma cell line. Diabetes. 32:1126-1133.

22. Laemmli, U. K. 1970. Cleavage of structural proteins during the assembly of the head of bacteriophage $T_{4}$. Nature (Lond.). 227:680-685.

23. Coates, M. E., and E. S. Holdsworth. 1961. Vitamin $D_{3}$ and absorption of calcium in the chick. Br. J. Nutr. 15:131-147.

24. Morrissey, R. L., D. T. Zolock, D. D. Bikle, R. N. Empson, Jr., and T. J. Bucci. 1978. Intestinal response to $1 \alpha, 25$-dihydroxycholecalciferol. I. RNA polymerase, alkaline phosphatase, calcium and phosphorus uptake in vitro and in vivo calcium transport and accumulation. Biochim. Biophys. Acta. 538:23-33.

25. Lowry, O. H., N. J. Rosebrough, A. L. Farr, and R. J. Randall. 1951. Protein measurement with the Folin phenol reagent. J. Biol. Chem. 193:265-285.

26. Hausamen, T. U., R. Helger, W. Rick, and W. Gross. 1967 Optimal conditions for the determination of serum alkaline phosphatase by a new kinetic method. Clin. Chim. Acta. 15:241-245.

27. Nemere, I., Y. Yoshimoto, and A. W. Norman. 1984. Calcium transport in perfused duodena from normal chicks: enhancement within fourteen minutes of exposure to 1,25-dihydroxyvitamin D. Endocrinology. 115:1476-1483.

28. Putkey, J. A., A. M. Spielvogel, R. D. Sauerheber, C. S. Dunlap, and A. W. Norman. 1982. Vitamin D-mediated intestinal calcium transport: effects of essential fatty acid deficiency and spin label studies of enterocyte membrane lipid fluidity. Biochim. Biophys. Acta. 688:177190.

29. Thomasset, M., A. Molla, O. Parke, and J. G. Demaille. 1981 Intestinal calmodulin and calcium-binding protein differ in their distribution and in the effect of vitamin D steroids on their concentration. FEBS (Fed. Eur. Biochem. Soc.) Lett. 127:13-16.

30. Verner, K., and A. Bretscher. 1985. Microvillus 110K-calmodulin: effects of nucleotides on isolated cytoskeletons and the interaction of the purified complex with F-actin. J. Cell Biol. 100:1455-1465.

31. Howe, C. L., and M. S. Mooseker. 1983. Characterization of the 110,000 dalton actin-calmodulin and membrane-binding protein from microvilli of intestinal epithelial cells. J. Cell Biol. 97:974-985.

32. Glenney, J. R., Jr., M. Osborn, and K. Weber. 1982. The intracellular localization of the microvillus $110 \mathrm{~K}$ protein, a component considered to be involved in side-on membrane attachment of F-actin. Exp. Cell Res. 138:199-205.

33. Coudrier, E., H. Reggio, and D. Louvard. 1981. Immunolocalization of the 110,000 molecular weight cytoskeletal protein of intestinal microvilli. J. Membr. Biol. 152:49-66.

34. Collins, J. H., and C. W. Borysenko. 1984. The 110,000 dalton actin and calmodulin binding protein from intestinal brush border is a myosin-like ATPase. J. Biol. Chem. 259:14128-14135.

35. Glenney, J. R., Jr., and P. Glenney. 1984. The microvillus 110 $\mathrm{K}$ cytoskeletal protein is an integral membrane protein. Cell. 37:743751 .

36. Glenney, J. R., Jr., and P. Glenney. 1985. Comparison of $\mathrm{Ca}^{++}$. regulated events in the intestinal brush border. J. Cell Biol. 100:754763.

37. Howe, C. L., T. C. S. Keller III, M. S. Mooseker, and R. H. Wasserman. 1982. Analysis of cytoskeletal proteins and calcium dependent regulation of structure in intestinal brush borders from rachitic chicks. Proc. Natl. Acad. Sci. USA. 79:1134-1138. 